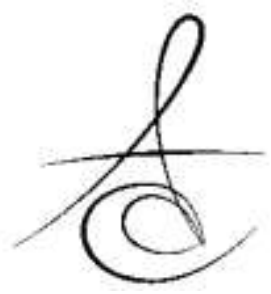

\section{EVALUATION OF REFERRAL OF CONE-BEAM CT INVESTIGATIONS AT A DENTOMAXILLOFACIAL RADIOLOGY CLINIC OF UNIVERSITY HOSPITAL}

\section{BİR ÜNİVERSİTE HASTANESİ DENTOMAKSİLLOFASİYAL RADYOLOJİ KLİNİĞİNDE KIBT İSTEMLERİNİN DEĞERLENDİRİLMESİ}

Doç. Dr. Hakan EREN*

Dr. Burcu KİRŞAN BÜYÜKKOÇAK***

Prof. Dr. Kaan ORHAN*

\author{
Dr. Beste İNCEOĞLU** \\ Dr. İrem EREN $* * * *$
}

Hakan Eren: ORCID ID: 0000-0001-9006-6836

Makale Kodu/Article code: 4066

Beste İnceoğlu: ORCID ID: 0000-0002-4633-3295

Makale Gönderilme tarihi; 07.05.2019

Burcu Kirșan Büyükkoçak: ORCID ID: 0000-0001-5354-1554

Kabul Tarihi: 14.01 .2020

İrem Eren: $O R C I D I D: 0000-0001-5347-8137$

DOI : $10.17567 /$ ataunidfd.674728

\begin{abstract}
Objective: Recent researches provided an overview for advantages, disadvantages and indications/contraindications of ConeBeam Computed Tomography (CBCT) as well as some thoughts on the current educational status of CBCT in dental schools. Reviews of recent publications reveal that $\mathrm{CBCT}$ is an important tool in the diagnostic process, even it plays an integral role in treatment planning and outcome assessment at different departments like maxillofacial surgery, orthodontics, periodontology and endodontics.

The aim of present study is to find out the indications and the most frequently used ones by reviewing the indications of CBCT at Dentomaxillofacial Radiology (DMFR) clinic, which were referred by other clinics/departments of the hospital.

Materials and Method: 1590 CBCT indications defined from 1503 patients and their reports retrieved from the archieves of the DMFR clinic. Besides; referral reports, and Field of View (FOV- region) were also noted.

Results: CBCT imaging has mostly focused on applications for dental implant planning, impacted tooth extraction, orthodontic purposes and temporomandibular joint imaging.

Conclusion:CBCT is a 3D diagnostic tool contributing additional information to the clinical situation if the appropriate indication is used with the right FOV selection. In addition, the recent spread of implant treatments has led to the use of CBCT for implant planning.
\end{abstract}

Key words: $\mathrm{CBCT}$, Indication, FOV, Applications of $\mathrm{CBCT}$

Öz

Amaç:Son araştırmalar, Konik Işınlı Bilgisayarlı Tomografi'nin (KIBT) avantajları, dezavantajları ve endikasyonları / kontrendikasyonları yanı sıra dişhekimliği okullarında verilen mevcut KIBT eğitimi ile ilgili geliştirilen fikirler hakkında genel bir bakış sağlamıștır. Son yayınların değerlendirmeleri KIBT'nin tanısal süreçte önemli bir araç olduğunu ortaya koymaktadır. Hatta maksillofasiyal cerrahi, ortodonti, periodontoloji ve endodonti gibi farklı bölümlerin tedavi planlama ve sonuç değerlendirmesinde ayrılmaz bir rol oynamaktadır.

Bu çalışmanın amacı, hastanenin diğer klinikleri / bölümleri tarafından yönlendirilen Dentomaksillofasiyal Radyoloji (DMFR) kliniğindeki KIBT endikasyonlarını gözden geçirerek KIBT endikasyonları ile bunlardan en sık kullanılanları ortaya çıkarmaktır.

Gereç ve Yöntem:1503 hastadan 1590 KIBT endikasyonu tanımlandı ve raporları DMFR kliniğinin arşivlerinden alındı, sevk raporları ve İnceleme Alanı (FOV bölgesi) da not edildi.

Bulgular:KIBT görüntüleme çoğunlukla implant planlaması, gömülü diş çekimi, ortodontik amaçlar ve temporomandibuler eklem görüntülemesi uygulamalarına odaklanmıştır.

Sonuç:KIBT, uygun FOV bölgesi seçiminde uygun endikasyon kullanıldığında klinik duruma ek bilgi sağlayan 3B tanılama aracıdır. Ek olarak implant tedavilerinin yaygınlaşması, implant planlaması için KIBT kullanımının da artmasına yol açmıştır. Anahtar kelimeler: KIBT, Endikasyon, FOV, KIBT Uygulamaları

\footnotetext{
** Ankara University Faculty of Dentistry, Dentomaxillofacial Radiology Dept., Ankara, Turkey

** Ankara University Faculty of Dentomaxillofacial Radiology, Ministry of Health Etimesgut Oral Health Center, Ankara,

*** Ankara University Faculty of Dentomaxillofacial Radiology, Ministry of Health Mamak Oral Health Center, Ankara, **** Ankara University Faculty of Dentistry, Endodontics Dept., Ankara.
}

Kaynakça Bilgisi: Eren H, İnceoğlu B, Kirşan Büyükkoçak B, Eren İ, Orhan H. Bir Üniversite Hastanesi Dentomaksillofasiyal Radyoloji Kliniğinde KIBT İstemlerinin Değerlendirilmesi. Atatürk Üniv Diş Hek Fak Derg 2020; 30: 167-73

Citation Information: Eren H, Inceoglu B, Kirşan Buyukkocak B, Eren I, Orhan H. Evaluation of Referral of Cone-Beam CT Investigations at a Dentomaxillofacial Radiology Clinic of University Hospital. J Dent Fac Atatürk Uni 2020; 30: 167-73. 
EREN, İNCEOĞLU,

KİRŞAN BÜYÜKKOÇAK,

EREN, ORHAN

\section{INTRODUCTION}

The conventional panoramic radiographic and/or full-mouth intraoral radiographic analysis has been used in dentistry as a routine standart of dental radiographic examination with some degree of distortion and magnification. ${ }^{1,2}$ But, maxillofacial region includes complex $3 \mathrm{D}$ anatomy and conventional 2D imaging modalities may fail to provide optimal visualization. So; indications for 3D imaging has started to find its place in dentistry in the last several decades for better visualization of maxillofaical region. $^{3}$

$\mathrm{CBCT}$ imaging provides 3D volumetric data construction of dental and associated maxillofacial structures with high isotropic spatial resolution and high dimensional accuracy. ${ }^{4}$ Recent advances in CBCT technology have allowed its commercial production and practical application in up-to-date patient care and dental education environment. ${ }^{5}$

CBCT device needs a single rotation dose to scan maxillofacial region with lower radiation when compared with multi-slice CT imaging modality, because of its lower tube power. ${ }^{6}$ On the other hand, its low tube power generates images with less contrast, so it is impossible to visualize soft tissues with $\mathrm{CBCT}$ imaging. ${ }^{7}$ However, regions with air-bone contrast structures like complex maxillofacial hard tissues can be monitorized easily. ${ }^{8}$ Besides, its low cost and easy-to-use design according to multi-slice CT increase the frequency of use in dental field.

The use of $\mathrm{CBCT}$ raises some questions such as; "Does CBCT offer additional value in the diagnosis process and treatment planning of clinical dentistry?" or, "Does 3D evaluation contribute to improved patient care and treatment outcomes?" Before answering these questions, it is important to understand the advantages, disadvantages, indications, risks and benefits for use of this 3D imaging modality. ${ }^{9}$ While radiologists generally know these issues, it is important that clinicians know about the basic features of $\mathrm{CBCT}$. Thus, The reason for the request of the dentists working in other dentistry fields is thought to be valuable in understanding the subject.

The aim of the present study is to find out the indications and the most frequently used ones by reviewing the indications of $\mathrm{CBCT}$ exams at a Dentomaxillofacial Radiology (DMFR) Clinic, which were referred by other clinics/departments of the hospital.

\section{MATERIALS AND METHOD}

CBCT request forms of 1590 CBCT indications defined from 1503 patients were analysed to find the department which most frequently requested 3D imaging, the most commonly used indications in claim, the most commonly used Field of View (FOV) size and region of interest, finally gender and average age of patients. There were repeated indications in the 87 of these patients. But, through these two repeated indications, CBCT examinations of these patients were identified as taken from the same region and requested from the same department. So, the number of statistically analyzed CBCT indications were higher than the number of patients and also number of CBCT requests. $\mathrm{CBCT}$ images were obtained by using Planmeca 3D Pro-face (Helsinki, Finland) 3D imaging device. Request forms were analysed under five headings; the specified CBCT indications, age-gender, the requesting department, FOV size and region.

The specified CBCT indications were classified into 20 groups as follows:

1- Post-operative control of dental implant surgery

2- Determination of relation between impacted third molar and mandibular canal

3- Dental implant planning

4- Evaluation of temporomandibular joint (TMJ)

5- Maxillofacial fractures

6- Assessment of odontogenic cysts and tumors

7- Surnumerary and/or impacted teeth (except third molars)

8- Cleft palate

9- Paranasal sinus

10- Evauation of anatomical structures

11- Orthognathic surgery planning

12-Salivary gland pathologies

13- Numbness, parethesia, control

14- Foreign body

15- Sinus lifting planning

16- Surgical complications

17- Periodontal bone loss

18- Orthodontic analysis

19- Root fracture

20- Root resorption, ankylosis, tooth anomalies The requesting departments were classified into 8 groups as follows:

1- Dentomaxillofacial Surgery

2- Periodontology

3- Dentomaxillofacial Radiology

4- Orthodonthics 


\section{5- Pedodontics \\ 6- Endodontics \\ 7- Prosthetics \\ 8- Restorative Dentistry}

The CBCT device used in the present study has 10 different FOV sizes and grouped as follows:

1- $50 \times 55 \mathrm{~mm}$

2- $100 \times 90 \mathrm{~mm}$

3- $100 \times 55 \mathrm{~mm}$

4- $130 \times 90 \mathrm{~mm}$

5- $130 \times 55 \mathrm{~mm}$

6- $230 \times 160 \mathrm{~mm}$

7- $230 \times 260 \mathrm{~mm}$

8- $130 \times 160 \mathrm{~mm}$

9- $130 \times 130 \mathrm{~mm}$

10-50x55 mm (TMJ pair)

Additionally, the region of interest where CBCT images were taken from, was also noted for each CBCT image. All data collected from the request forms that retrieved from 4 years of archives (2014-2017) were statistically analysed by using frequency distribution tables.

\section{RESULTS}

During 4 years period, 1503 patients were referred to DMFR clinic by other clinics/departments, and a total of 1590 CBCT indications were defined from them. 831 female (55\%) and 672 (45\%) male patients were referred to radiology clinic for CBCT examination (Graphic 1). Average age of female patients was 40 years, including, the youngest one was 6 years old and the oldest one was 84 years old. In addition, average age of male patients was also 40 years, including, the youngest one was 8 years old and the oldest one was 77 years old. 61 patients under the age of $18(11,5 \%)$ underwent CBCT examination for several indications (Graphic 2).

Graphic 3 shows the distribution of departments which requested CBCT by percentages. Rate of requests from dentomaxillofacial surgery department was the most with the percentage of $45,7 \%$, while, the second department was dentomaxillofacial radiology with the percentage of $21 \%$ and the third department was periodontology with the percentage of $18,4 \%$. The department which requested $\mathrm{CBCT}$ imagingthe least was found as restorative dentistry clinic with the percentage of $0,2 \%$.

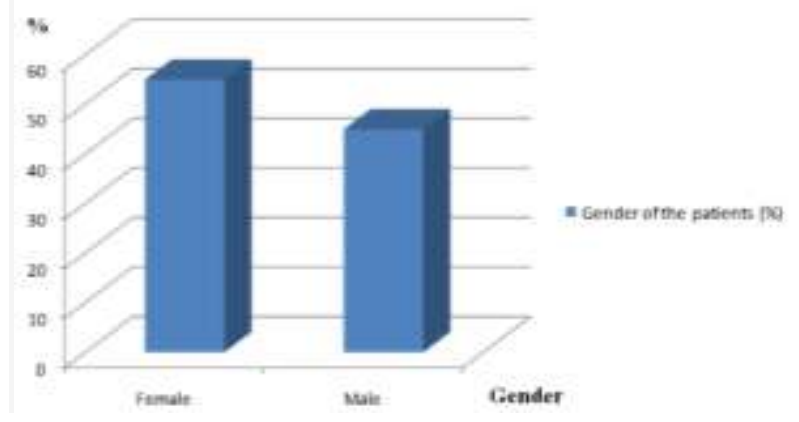

Graphic 1. Distribution of patients by gender

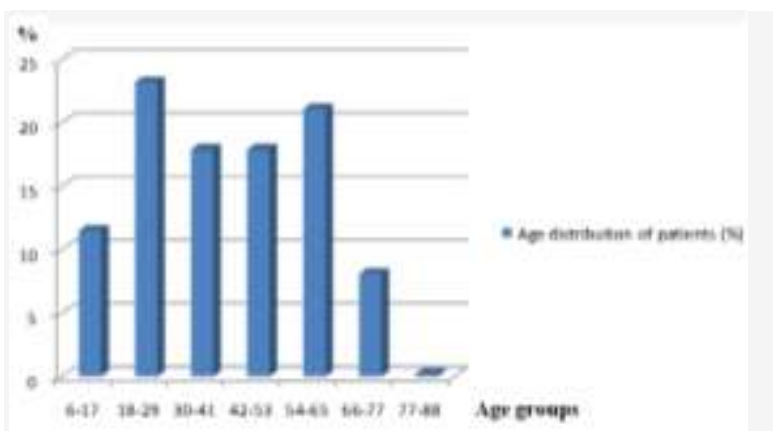

Graphic 2. Distribution of patients by age groups

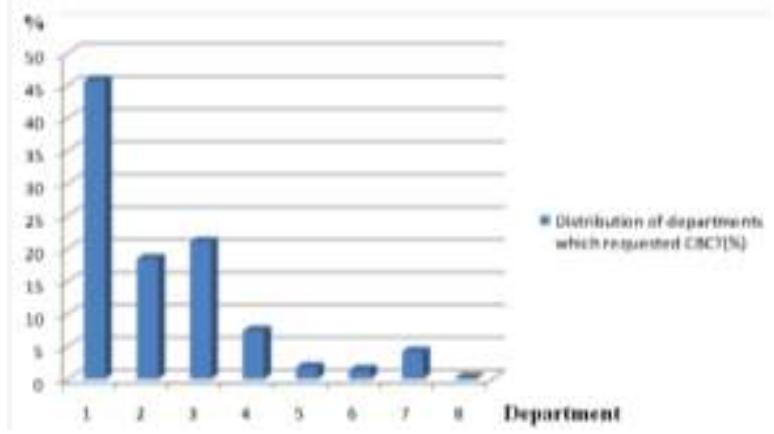

Graphic 3. Distribution of departments which requested CBCT imaging

Graphic 4 shows the most frequently used FOV sizes. The FOV size of $130 \times 90 \mathrm{~mm}$ was found to be the most frequently used size $(26,3 \%)$. The ensuing three places occupied by FOV sizes taken from only one jaw, as follows 50x55 mm (19,4\%), 130x55 mm $(19,4 \%)$ and $100 \times 55 \mathrm{~mm}(18,8 \%)$ respectively. So that $54,3 \%$ of all received $\mathrm{CBCT}$ images were taken from one jaw while the proportion of CBCT images taken from both jaws were $37,5 \%$. 
EREN, İNCEOĞLU,

KİRŞAN BÜYÜKKOÇAK,

EREN, ORHAN

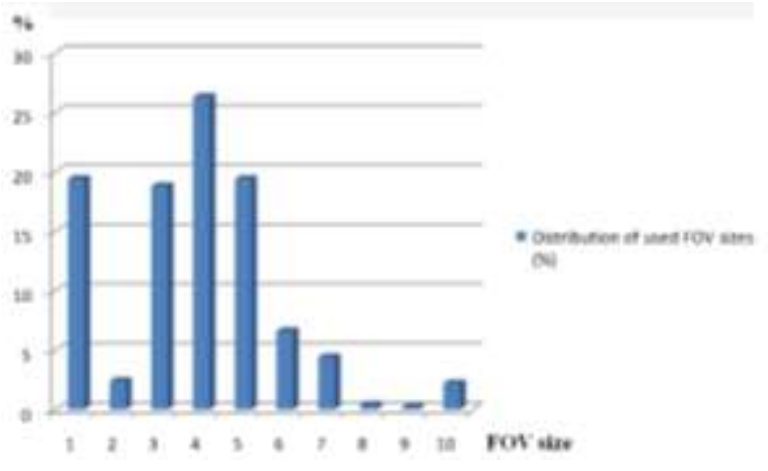

Graphic 4. Distribution of used FOV sizes in CBCT examinations included in the study

Graphic 5 shows the distribution of CBCT indications. The most frequently used indication of $\mathrm{CBCT}$ request was dental implant planning with the percentage of $40 \%$. The requests for indications of assessment of odontogenic cysts and tumors (16,6\%), evaluation of relationship between impacted third molar (10,9\%) and mandibular canal and surnumerary and/or impacted teeth except third molars $(9,1 \%)$ were followed respectively. CBCT requests for foreign body and surgical complications were the least used indications with $0,2 \%$ and $0,4 \%$ respectively.

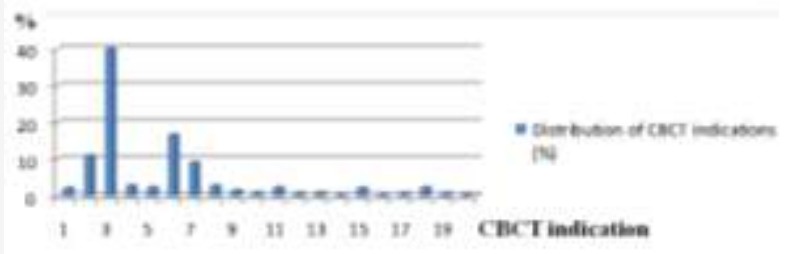

Graphic 5. Distribution of initial indications for $\mathrm{CBCT}$ requests
Table 1 shows the distribution of CBCT indications among age groups. Age group that applied the most was the 18-29 age group with the percentage of $23,2 \%$ approximately, followed by 54 65 age group with the percentage of $21,1 \%$ approximately. The 6-17 age group mostly applied for surnumerary and/or unerupted teeth except third molars (69 of 183 patients) and 18-29 age group mostly applied for evaluation of relationship between impacted third molar and mandibular canal (96 of 369 patients). The most frequently used indication of CBCT imaging was dental implant planning for all other age groups over age of 30 .

\section{DISCUSSION}

CBCT examinations start to replace 2D imaging in recent years. ${ }^{10,11}$ The main parameter that limits the use of CBCT especially in children is radiation dose, when it is compared with panoramic imaging. But, CBCT is still a good alternative to CT as an imaging technique of bony structures, because of lower irradiation in comparison with CT. ${ }^{12,13}$ Also, guidelines recommend $\mathrm{CBCT}$ as an alternative 3D imaging tool to CT when necessary. ${ }^{14}$ Present study showed that there were 183 patients under the age of $18(11,5 \%)$ who were considered as child that underwent CBCT scan for the examination of bony structures in head and neck region. Besides, it was found that irradiation was most commonly performed for the indications of assessment of odontogenic cysts and tumors, surnumerary and/or impacted teeth (except third molars) and cleft palate indications in 617 age group. Frequency of CBCT use in children is

Table 1. Distribution of initial CBCT indications for requests among age groups

\begin{tabular}{|c|c|c|c|c|c|c|c|c|c|c|c|c|c|c|c|c|c|c|c|c|c|c|}
\hline & & \multicolumn{20}{|c|}{ Indications } & \multirow[t]{2}{*}{ Total: } \\
\hline & & 1 & 2 & 3 & 4 & 5 & 6 & 7 & 8 & 9 & 10 & 11 & 12 & 13 & 14 & 15 & 16 & 17 & 18 & 19 & 20 & \\
\hline \multirow[t]{7}{*}{ Age Groups } & 6-17 & 0 & 6 & 3 & 0 & 6 & 54 & 69 & 33 & 0 & 0 & 0 & 0 & 0 & 0 & 0 & 0 & 0 & 6 & 3 & 3 & $183(11,5 \%)$ \\
\hline & 18-29 & 9 & 96 & 66 & 12 & 18 & 42 & 39 & 9 & 12 & 6 & 27 & 0 & 3 & 0 & 0 & 3 & 0 & 18 & 6 & 3 & $369(23,2 \%)$ \\
\hline & $30-41$ & 3 & 48 & 102 & 12 & 6 & 60 & 15 & 3 & 3 & 6 & 3 & 6 & 3 & 0 & 6 & 0 & 3 & 3 & 0 & 3 & $285(17,9 \%)$ \\
\hline & $42-53$ & 9 & 18 & 141 & 6 & 6 & 54 & 9 & 0 & 3 & 0 & 3 & 3 & 6 & 0 & 15 & 0 & 3 & 6 & 3 & 0 & $285(17,9 \%)$ \\
\hline & $54-65$ & 6 & 3 & 243 & 12 & 0 & 24 & 6 & 0 & 6 & 3 & 3 & 3 & 3 & 0 & 12 & 3 & 6 & 3 & 0 & 0 & $336(21,1 \%)$ \\
\hline & $66-77$ & 3 & 3 & 81 & 3 & 0 & 30 & 6 & 0 & 0 & 0 & 0 & 0 & 0 & 3 & 0 & 0 & 0 & 0 & 0 & 0 & $129(8,1 \%)$ \\
\hline & $77-88$ & 3 & 0 & 0 & 0 & 0 & 0 & 0 & 0 & 0 & 0 & 0 & 0 & 0 & 0 & 0 & 0 & 0 & 0 & 0 & 0 & $3(0,2 \%)$ \\
\hline Total: & & 33 & 174 & 636 & 45 & 36 & 264 & 144 & 45 & 24 & 15 & 36 & 12 & 15 & 3 & 33 & 6 & 12 & 36 & 12 & 9 & 1590 \\
\hline
\end{tabular}


EREN, İNCEOĞLU,

KİRŞAN BÜYÜKKOÇAK,

EREN, ORHAN

close to those of CBCT usage frequency in the other age ranges. Moreover, some of the most frequently used indications in this age group (assessment of odontogenic cysts and tumors and cleft palate) can probably require large FOV size. So, special radiation protections like adjusting the smallest possible FOV size to region of interest and reducing the current of device although allowing patient to wear lead aprons and thyroid protector for the prevention against harmful effects of irradiation should be performed especially for children. ${ }^{15-17}$

According to the results of the present study, the most common request of CBCT in dentistry area is dentomaxillofacial surgery $(45,7 \%)$ with most requested indication of dental implant planning (40\%). It is important to determine the surgical area three dimensionally with CBCT, which is essential for planning of dental implant or other surgical procedures. ${ }^{18,19}$ The diagnostic ability of this 3D technology strengthen the clinician with the necessary tools to avoid potential complications and increases the clinician's confidence and predictability associated with implant dentistry. ${ }^{20}$

Generally, all CBCT units have several imaging protocols available that manufacturer's prescribed, so, those can be adjusted to most appropriate setup according to indication of imaging and anatomical characteristics of region of interest. ${ }^{21}$ Based on ALADA principle ("As Low As Diagnostically Acceptable"), it is important to choose the appropriate protocol that provides the lowest dose to the patient while providing sufficient diagnostic information. Also, the radiation dose absorbed by the patient originated from selected FOV and exposure parameters. ${ }^{22}$ Generally, CBCT devices have standardized exposure parameters due to patient size and it can be selected by operator in connection with patient's age and size. Furthermore, the CBCT device used in the present study had standardized 5 different patient size exposure parameters that could be adjusted automatically due to patient size. Thus, main tool to reduce the radiation dose was selection of FOV size. Because, it is a variable parameter selected by the operator according to its indication regardless of the size of the patient.

FOV sizes available in dental CBCT systems can be in a variety of dimensions which are suitable from a single dentoalveolar region $\left(4 \times 4 \mathrm{~cm}^{2}\right.$ or $\left.5 \times 5 \mathrm{~cm}^{2}\right)$ to full craniofacial imaging (from approximately $15 \times$ $15 \mathrm{~cm}^{2}$ up to $23 \times 26 \mathrm{~cm}^{2}$ ). The dimensions of the FOV vary according to the size and shape of the detector, the beam projection geometry and the device ability to collimate the beam. ${ }^{23,24}$ According to the results of study, $54,3 \%$ of all received CBCT images were taken from one jaw while the proportion of CBCT images taken from both jaws were $37,5 \%$. These results show that operators are paying attention to reduction of radiation dose by selecting a much smaller and possible FOV size more in the present study. Additionally, the use of 10 different FOV sizes in the present study within 2 years time shows that clinicians which requested CBCT take care to choose suitable FOV size for each indication.

Implant surgery has started to take place a large proportion in dentistry in recent years, which has led to a greater number of clinicians participating in surgical planning and participation in surgery. Although, both implant companies and imaging centers are encouraging the use of CBCT imaging to increase their chances of success and to have a word on the market. For these reasons, the most frequently used indication of CBCT request is dental implant planning. ${ }^{10,11}$ The results of the present study also confirm the same in parallel with this situation with percentage of $40 \%$ over the age groups of 30 , and the most requests were performed in 54-65 age group for dental implant planning on the side. According to findings, the other most preferred CBCT indications were determination of relation between impacted third molar and mandibular canal, assessment of odontogenic cysts and tumors and surnumerary and/or impacted teeth (except third molars) which were requested more than dental implant planning for age groups under age of. ${ }^{30}$ The cause of age-related indication differences is seem to be pathologies that occur at different ages are also different. For example, while impacted third molar, surnumerary and/or impacted teeth (except third molars) or cleft lip palate pathologies are seen more frequently in children, dental implant surgery related with tooth deficiencies or dental prosthesis needover 30 years of age become more important. ${ }^{25-29}$

\section{CONCLUSIONS}

CBCT is a $3 \mathrm{D}$ diagnostic tool contributing additional information to the clinical situation if the appropriate indication is used with the right FOV selection. Thus, CBCT can be used most effectively and patients can be prevented from being exposed to unnecessary radiation. 
EREN, İNCEOĞLU,

KİRŞAN BÜYÜKKOÇAK,

EREN, ORHAN

Conflict of interest statements

The authors declare that they have no conflict of interest

\section{REFERENCES}

1. Park JB. The evaluation of digital panoramic radiographs taken for implant dentistry in the daily practice. Med Oral Patol Oral Cir Bucal 2010; 15:663-6.

2. Rushton VE, Horner $\mathrm{K}$, Worthington HV. The quality of panoramic radiographs in a sample of general dental practices. Br Dent J 1999;186:6303.

3. Mayil M, Keser G, Namdar Pekiner F. CBCT Images of Anatomic Landmarks in Maxillofacial Region MÜSBED 2014; 4:232-40.

4. Shetty $H$, Hegde $P$, Shetty A, Hegde MN. CBCT Imaging- The Dentists Third Eye: A Literature Based Review. Indian J Stomatology 2014; 5: 95101.

5. Venkatesh E, Elluru SV. Cone beam computed tomography: basics and applications in dentistry. J Istanbul Univ Fac Dent 2017;51:102-21.

6. Krishnamoorthy B, Mamatha N, Kumar VA. TMJ imaging by CBCT: Current scenario. Ann Maxillofac Surg 2013; 3: 80-3.

7. Schegerer A, Lechel U, Ritter M, Weisser G, Fink C, Brix G. Dose and Image Quality of Cone-Beam Computed Tomography as Compared With Conventional Multislice Computed Tomography in Abdominal Imaging. Investigative Radiology. 2014;49:675-84.

8. Jaju PP, Jaju SP. Clinical utility of dental conebeam computed tomography: current perspectives. Clin Cosmet Investig Dent 2014; 6: 29-43.

9. Adibi S, Zhang W, Servos T, O'Neill PN. Cone Beam Computed Tomography in Dentistry: What Dental Educators and Learners Should Know. J Dent Educ 2012; 76:1437-42.

10. Carter JB, Stone, Clark RS, Mercer JE. Applications of Cone-Beam Computed Tomography in Oral and Maxillofacial Surgery: An Overview of Published Indications and Clinical Usage in United States Academic Centers and Oral and Maxillofacial Surgery Practices. J Oral Maxillofac Surg 2016; 74:668-79.
11. Temur KT, Hatipoglu O. Awareness And Use Of Cone-Beam Computed Tomography (CBCT) Of Turkish Dentist. Atatürk Üniv Diş Hek Fak Derg 2019; 29:169-75.

12. Stratemann SA, Huang JC, Maki K, et al. Comparison ofcone beam computed tomography imaging with physicalmeasures. Dentomaxillofac Radiol 2008;37:80-93.

13. Eggers G, Klein J, Welzel T, et al. Geometric accuracy of digital volume tomography and conventional computed tomography. $\mathrm{Br} \mathrm{J}$ Oral Maxillofac Surg 2008;46:639-44.

14. Stuck BA, Hulse R, Barth TJ. Intraoperative cone beamcomputed tomography in the management of facial fractures. Int J Oral Maxillofac Surg 2012; 41:1171-5.

15. Tsapaki V, Radiation protection in dental radiology - Recent advances and future directions. Phys Med 2017 Dec;44:222-6.

16. European Commission. European Guidelines on Radiation Protection in Dental Radiology; Radiation Protection, Luxembourg 2004:Report 136.

17. Goren A, Prins R, Dauer L, Quinn B, Al-Najjar $A$, Faber $R$, et al.Effect of leaded glasses and thyroid shielding on cone beam $\mathrm{CT}$ radiation dose in an adult female phantom. Dentomaxillofac Radiol 2013;42:p. 20120260.

18. Longoni S, Sartori M, Braun M, et al. Lingual vascular canals of the mandible: The risk of bleeding complications during implant procedures. Imlant Dent 2007;16:131-8.

19. Makris N, Stamatakis H, Syriopoulos K, et al. Evaluation of the visibility and the course of the mandibular incisive canal and the lingual foramen using cone-beam computed tomography. Clin Oral Imlants Res 2010;21:766-71.

20. Stuart J. Implant complications associated with two and three dimensional diagnostic imaging technologies. In: Ganz SD, eds. Dental Implant Complications: Etiology, Prevention, and Treatment. 2nd ed. Hoboken, NJ: Jhon Wiley \& Sns; 2015:102-31.

21. Nascimento HAR, Andrade MEA, Frazão MAG, Nascimento EHL, Ramos-Perez FMM, Freitas DQ. Dosimetry in CBCT with Different Protocols: Emphasis on Small FOVs Including Exams for TMJ. Braz Dnt J 2017; 28:511-6.

22. White SC, Scarfe WC, Schulze RK, Lurie AG, Douglass JM, Farman AG, et al. The image gently in dentistry campaign: promotion of responsible

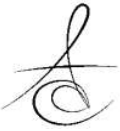


use of maxillofacial radiology in dentistry for children. Oral Surg Oral Med Oral Pathol Oral Radiol 2014; 118: 257-61.

23. Kiljunen $T$, Kaasalainen $T$, Suomalainen $A$, Kortesniemi M.Dental cone beam CT: A review. Physica Medica 2015; 31:844-60.

24. ScarfeWC, Li Z, Aboelmaaty W, Scott SA, Farman AG. Maxillofacial cone beam computed tomography: essence, elements and steps to interpretation. Aust Dent]. 2012;57: 46-60.

25. Isman O, Yilmaz HH, Aktan AM, Yilmaz B. Indications for cone beam computed tomography in childrenand young patients in a Turkish subpopulation. Int J Paediatr Dent 2017; 27:18390.

26. Mandelaris GA, Scheyer ET, Evans M, Kim D, McAllister B, Nevins ML, et al. American Academy of PeriodontologyBest Evidence Consensus Statementon Selected Oral Applications for ConeBeam Computed Tomography. J Periodontol 2017; 88: 939-45.

27. Nematolahi H, Abadi H, Mohammadzade Z, Soofiani Ghadim M. The use of cone beam computed tomography(CBCT) to determine supernumerary and impacted teeth position in pediatric patients: a case report. J Dent Res Dent Clin Dent Prospects 2013;7:47-50.

28. Kapila S, Conley RS, Harrell WE Jr. The currentstatus of cone beam computed tomography imaging in orthodontics. Dentomaxillofac Radiol 2011; 40:24-34.

29. European Commission on Radiation Protection. Evidence Based Guidelines on Cone Beam CT for Dental and Maxillofacial Radiology. Luxembourg: Office for Official Publications of the European Communities, 2012:Report 172.

\section{Yazışma Adresi}

Hakan Eren,

Assoc Prof, Ankara University

Faculty of Dentistry, D

entomaxillofacial Radiology Dept.,

Ankara, Turkey

Mobile: 00905068691611

Email: dthakaneren@yahoo.com.tr 